\title{
RESULTS OF MANDARIN PLANTATIONS MONITORING DAMAGED BY FROST AND EVALUATION IN GEORGIA
}

\author{
Khalvashi N., Chief scientist, Department of Biodiversity Monitoring and Conservation, Institute of \\ Phytopathology and Biodiversity, Batumi Shota Rustaveli state university, Georgia \\ Memarne G., Chief scientist, Institute of Phytopathology and Biodiversity, Batumi Shota Rustaveli \\ state university, Georgia \\ Baratashvili D., Professor, Department of biology, Batumi Shota Rustaveli state university, Georgia \\ Kedelidze N., Senior scientist, Department of Biodiversity Monitoring and Conservation, Institute of \\ Phytopathology and Biodiversity, Batumi Shota Rustaveli state university, Georgia \\ Gabaidze M., Senior scientist, Department of Plant Diseases Monitoring, Molecular Biology, Institute \\ of Phytopathology and Biodiversity, Batumi Shota Rustaveli State University, Georgia \\ Gorjomeladze I., PhD student, Akaki Tsereteli State University, Kutaisi, Georgia
}

DOI: https://doi.org/10.31435/rsglobal_conf/30032021/7477

Abstract. In the paper is discussed the results of mandarin plantations monitoring damaged by frost in winter. Despite the centuries-old history of citrus production in Georgia, the danger of frost damage remains a major limiting factor for the spread of citrus. The monitoring revealed that although the temperature was quite critical for mandarin in February $2020\left(-11-12^{\circ} \mathrm{C}\right.$, in some places $\left.-14^{\circ} \mathrm{C}\right)$, the frost damage to the plantations was not high, but was inhomogeneous. Observations revealed that the damage to mandarin plantations was due not only to the impact of low temperatures, but also to many other factors that had a significant impact on the degree of damage to the plantations. Based on the analysis of monitoring results and multi-year data, it was found that the risk of frost damage to the citrus in winter in Georgia due to global warming is significantly reduced compared to previous years, but the incidence of autumn-spring frosts has increased which indicates the adaptation of the citrus crops to the climatic conditions of Georgia.

Keywords: Citrus, Frost, Breeding, Mandarin, Frost resistant, plantation.

Introduction. The subtropical zone of Georgia (Black Sea coastline), where citrus crops are grown, is located farthest north of the subtropical zone and exceeds the geographical boundary of citrus distribution in the world. The climatic peculiarity of the Adjara region is determined by two main factors: The Black Sea, which accumulates heat in summer and gradually releases it along the coast, and on the other hand, the high mountains of the Caucasus, which prevent the entry of cold air masses from the north. Accordingly, in the subtropical zone of western Georgia, winters are moderately warm and characterized by abundant precipitation, where the sum of active temperatures ranges from 3500 to 5500 , the average annual temperature reaches $+14+15^{\circ} \mathrm{C}$, the annual sum of atmospheric precipitation is from $1300 \mathrm{~mm}$ to $3000 \mathrm{~mm}$, air humidity is $80-95 \%$, and the minimum air temperature drops to $-6-7^{\circ} \mathrm{C}$ in some years and sometimes even more (Elizbarashvili E. 2017).

Although the history of the spread of citrus crops in Georgia is related to the distant past and dates back to the $7^{\text {th }}-8^{\text {th }}$ centuries. It's spread for industrial purposes dates back to the early $19^{\text {th }}$ century. In different periods, up to 120 varieties of up to 20 species of citrus were introduced and studied in Georgia, and about 200 varieties of citrus, hybrids, clones and mutant forms were bred by Georgian breeders (List of var. 1990). Despite such diversity, the most adapted to the soil-climatic conditions of Georgia is the frostresistant and high-yielding variety Satsuma mandarin (Citrus Unshiu Marcow). The variety originated in China (Hodgson R. 1967), and was introduced to Georgia from Japan. It covers $80 \%$ of the area occupied by citrus in Georgia, where about 20,000 farmers are employed (Baratashvili D., and Khalvashi N. 2016).

Cold tolerance in many plant species is not constitutively expressed. It is induced in response to reduction in daylength and the exposure to non-freezing chilling temperatures. A period of acclimation is important for inducing cold tolerance in Citrus. Most species in the genus Citrus are highly sensitive to low temperatures. Among commercial citrus fruits, Satsuma mandarin is known to be the most frost-resistant species. Studies by various scientists have shown that it can withstand $-9.4^{\circ} \mathrm{C}$ temperature (Yelenosky G. 1985), $-11.1^{\circ} \mathrm{C}$ (Gerber J. and Hashemi F.1965) and $-11.0^{\circ} \mathrm{C}$ (Anderson J. et al., 1983). 
It is known that frost resistance or the manifestation of the reaction norm (trait) are related not to one of the genes, but, like many other traits are encoded in the genetic machinery of plant cells and is controlled by many genes. These genes are dormant during the growing season and are activated only when the plant has a critical temperature and a light regime changes during the growing season (He L. et al., 2012; Lang G. et al., 2012; Zhang C. et al., 2005). Warm weather in the autumn prevents the plant from entering a dormant state and becomes more susceptible to frost (Davies F. and Albrigo J., 1994).

It is very important to produce frost-resistant varieties for the production of citrus, for which it is necessary to involve frost-resistant species in the selection processes. However, it should be noted that the use of frost-resistant species within the gene pool of citrus is complicated by many factors: prolonged juvenile (early plant growth) period, sexual incompatibility, polyembryonia (apomixis), heterozygosity, inbreeding (Grosser J. and Gmitter F., 1990; Soost R. and Cameron J., 1975; Soost R. and Roose M. 1990). Recently, genetic modification technologies such as protoplasm transformation (Fleming et al., 2000; Grosser J. and Gmitter F., 1990), particle bombardment (Yao J. et al., 1996), mediator agro-bacterial transformations (Luth D. and Moore J., 1999; Moore J. et al., 1992) and others, the use of which may lead to the formation of genotypes that will have both frost-resistant genes and genes that determine fruit taste and quality.

Proper selection of rootstocks is also important to increase the frost resistance of citrus fruits, as during the acclimatization process, gene expression takes place differently in rootstocks and grafts, leading to frost resistance of citrus (He L. et. Al., 2012; Zhang C. et al., 2005; Ping L., 2005). Frost replication genes have been identified in many species of the orange subfamily - Poncirus trifoliata (L), C. grandis, C. paradisi, C. sinensis, C. Jambhiri (He L. et al., 2012; Long G. et al., 2012; Richard L. 2005; Mehtap S. and Moore G, 2006). Studies have shown that the most frostresistant rootstock is Poncirus trifoliata, which can withstand $-30^{\circ} \mathrm{C}$ (Long G. et al., 2012) and is the most compatible among other related genera of Citrus and Poncirus. Its use as a rootstock increases the frost resistance of citrus fruits (Ebel R. et. Al., 2005; Huang Y. et al. 2011). Various frost-resistant species belonging to the genus Citrus have been studied and tested in the climatic conditions of Georgia (Poncirus trifoliata (L), C. Insitorum Mabb, C. junos Yuzu Sieb. Ex Tan., C. Wilsoni Tan., C. Aurantium (L), C. ichangensis Sw., C. myrtifolia Raf., C. yuko Hor. ex Tan., C. reshni Tan.). Poncirus trifoliata $\mathrm{L}$. was considered to be the best among them, therefore all species of citrus in Georgia are propagated on the root of trifoliata (Tatarishvili A. 1980).

Material and methods. The aim of the study was to monitor mandarin plantations in the Adjara region after the frosty winter, to assess the degree of frost damage and analyze multi-year data. After the severe winter of 2019-2020, monitoring was conducted to assess the degree of damage to mandarin plantations in 2 municipalities of Adjara region (Kobuleti and Khelvachauri), which account for up to $70 \%$ of citrus fruits produced in Georgia. During the monitoring, we considered that the plantation was cultivated with the same mandarin variety (Unshiu). As the Adjara region is distinguished by the diversity of terrain, sometimes different temperatures are observed in the adjacent plots (neighbors), therefore we monitored both in the lowlands at 5-10 $\mathrm{m}$ above sea level and in high places (250-400 m). During the monitoring we took into account other factors such as: slope exposure, distance from the sea, the presence of a windbreak, garden age, soil type, garden care conditions, altitude, etc.

To assess the degree of frost damage under natural conditions, plantations were mainly monitored after the onset of wintering and growth renewal (vegetation period) in the spring and continued until the end of the second vegetation period. We made a final assessment of the degree of frost damage when the result of plant damage was fully identified.

The assessment took into account the general condition of the plantation and not the degree of damage to individual plants. We assessed the degree of damage to various organs of the plant (leaves, young shoots, main branches) visually, which was expressed as a percentage (from 1\% to -100\%). The final assessment of damage was made on a five-point scale (Surguladze Sh., 1975).

- the plots where no damage was observed was assessed with - 0 point;

- the plots that had damaged $50 \%$ of the leaves and roughed only part of the tips of young shoots (twigs) were assessed with - 1 point;

- the plots that had damaged $100 \%$ of the leaves and young shoots (tips of twigs of the $2^{\text {nd }}$ vegetation) were evaluated with - 2 points; 

-3 points;

- the plots that had $100 \%$ damaged leaves and $100 \%$ of annual growths were evaluated with -4 points;

- the plots that had damaged leaves, main branches and part of the stem were evaluated with

- the plots that were completely damaged, up to the root collar were evaluated with - 5 points;

Results and Discussion. Low temperatures remain the main risk factor for citrus production in Georgia. The subtropical zone of Adjara region is characterized by quite abundant rainfall and minimal winter temperatures, which are mainly manifested in autumn and spring. This is the period with the highest risk during the annual cycle of plant growth and dormancy, as citrus fruits are most exposed to the negative effects of low temperatures and are damaged during this period. Although there are many ways to prevent frostbite today, it is costly and most Georgian farmers are unable to take preventive measures.

In the subtropical zone of Georgia (Adjara) November-December 2019 were characterized by quite warm and humid weather, which caused the late transition of citrus to winter rest. Added to this was the fact that in 2019 mandarins were abundantly harvested, so the nutrients produced by the leaves were completely spent on fruit formation, the vegetative organs failed to prepare for winter and the plant was delayed to a resting state, which had a significant impact on the degree of damage.

At the end of January 2020, cold air masses began to enter Georgia from the north, which led to a sharp drop in temperature and in most parts of the subtropical zone of Georgia (citrus distribution zone) in February the minimum temperature dropped to $-10^{\circ} \mathrm{C}$, in some places $-11-12^{\circ} \mathrm{C}$, and in some parts - Reached $14^{\circ} \mathrm{C}$. Added to this were rainless and cloudless weather, which further increased the likelihood of citrus freezing.

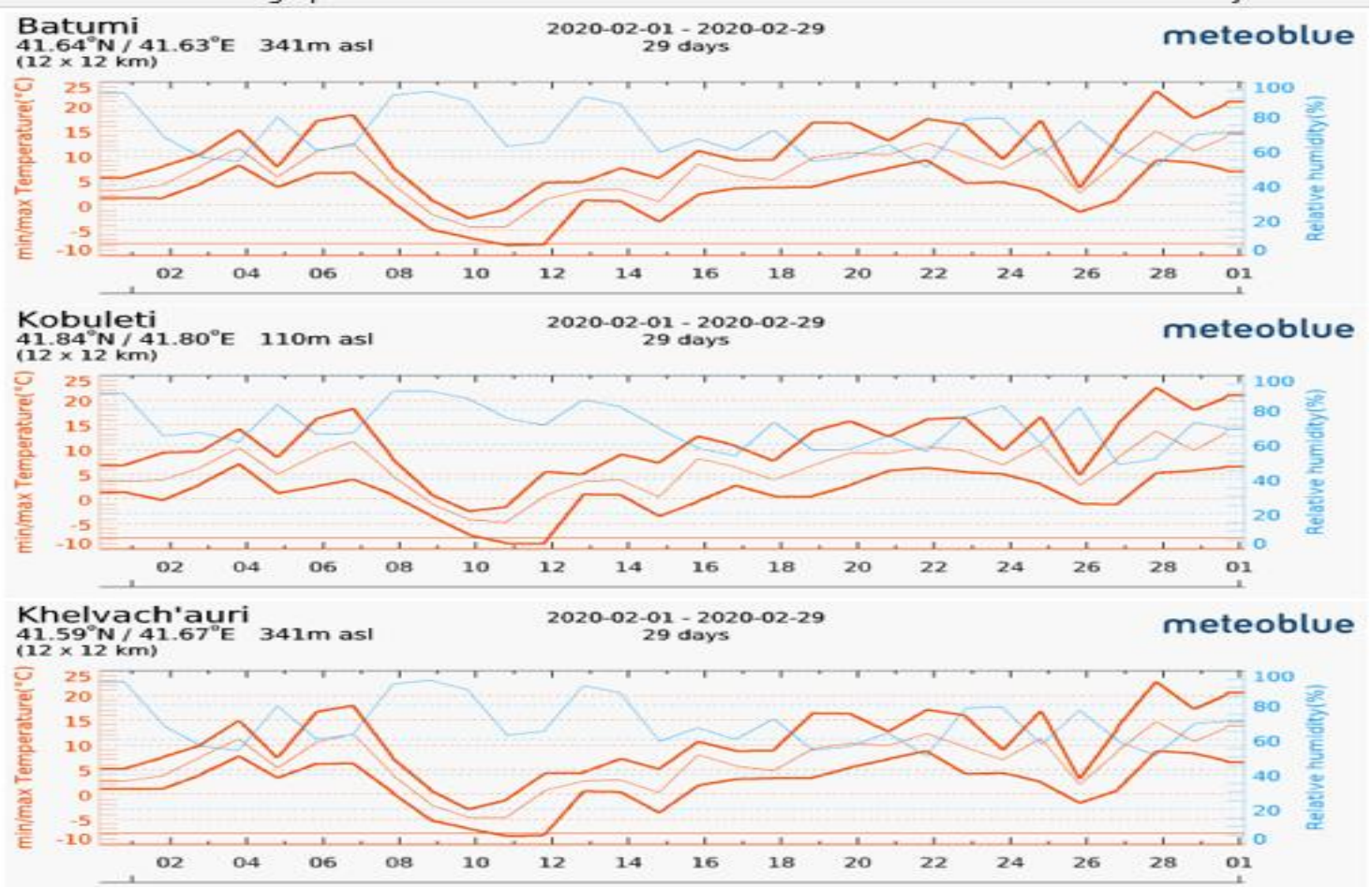

Fig.1. Meteorological data for February 2020 according to different municipalities

The diagram shows the temperature of 2 municipalities of Adjara region (Kobuleti, Khelvachauri) and the city of Batumi in February 2020. These data represent the average indicators of the subtropical zone of Adjara, although they do not fully reflect the situation in individual plantations, which had a significant impact on the quality of frost damage in different terrain conditions. As the subtropical zone of Adjara is characterized by diversity of relief, so the minimum temperatures could not be similar even in adjacent plots, therefore the quality of frost damage of mandarin plantations in the Adjara region was heterogeneous. 
Table 1. Degree of frost damage in plantations with different relief in Adjara region according to different villages

\begin{tabular}{|c|c|c|c|c|c|c|}
\hline Municipality & $\begin{array}{l}\text { Populated } \\
\text { area } \\
\text { (village) }\end{array}$ & Coordinates & M. asl & $\begin{array}{c}\text { Min. } \\
\text { Temperature } \\
\left({ }^{\circ} \mathrm{C}\right)\end{array}$ & $\begin{array}{l}\text { Distance } \\
\text { from the } \\
\text { sea in } \mathrm{m}\end{array}$ & $\begin{array}{c}\text { Degree of } \\
\text { damage } \\
\text { (points) }\end{array}$ \\
\hline \multirow[t]{10}{*}{ Khelvachauri } & Sarpi & $\begin{array}{l}41^{\circ} 63^{\prime} 37^{\prime \prime} \mathrm{N} \\
41^{\circ} 63^{\prime} 19^{\prime \prime} \mathrm{E}\end{array}$ & 60 & -8 & $50-105$ & 1 point \\
\hline & Gonio & $\begin{array}{l}41^{\circ} 55^{\prime} 00^{\prime \prime} \mathrm{N} \\
41^{\circ} 56^{\prime} 19^{\prime \prime} \mathrm{E}\end{array}$ & 50 & -8 & $30-600$ & 1 point \\
\hline & Akhalisopeli & $\begin{array}{l}41^{\circ} 57^{\prime} 09^{\prime \prime} \mathrm{N} \\
41^{\circ} 59^{\prime} 14^{\prime \prime} \mathrm{E}\end{array}$ & 130 & -9 & 2500 & 1 point \\
\hline & Makho & $\begin{array}{l}41^{\circ} 33^{\prime} 24^{\prime \prime} \mathrm{N} \\
41^{\circ} 40^{\prime} 09^{\prime \prime} \mathrm{E}\end{array}$ & 15 & -10 & 3000 & 3 points \\
\hline & Akhalsheni & $\begin{array}{l}41^{\circ} 37^{\prime} 38^{\prime \prime} \mathrm{N} \\
41^{\circ} 43^{\prime} 14^{\prime \prime} \mathrm{E}\end{array}$ & 140 & -11 & 9000 & 1 point \\
\hline & Makhvilauri & $\begin{array}{l}41^{\circ} 35^{\prime} 57^{\prime \prime} \mathrm{N} \\
41^{\circ} 39^{\prime} 36^{\prime \prime} \mathrm{E}\end{array}$ & 185 & -11 & $2000-2500$ & 1 point \\
\hline & Peria & $\begin{array}{l}41^{\circ} 38^{\prime} 00^{\prime \prime} \mathrm{N} \\
41^{\circ} 39^{\prime} 05^{\prime \prime} \mathrm{E}\end{array}$ & 207 & -9 & $1500-2000$ & 0 point \\
\hline & Ortabatumi & $\begin{array}{l}41^{\circ} 38^{\prime} 58^{\prime \prime} \mathrm{N} \\
41^{\circ} 43^{\prime} 26^{\prime \prime} \mathrm{E}\end{array}$ & 160 & -10 & $1200-2500$ & 0 point \\
\hline & Agara & $\begin{array}{l}41^{\circ} 39^{\prime} 05^{\prime \prime} \mathrm{N} \\
41^{\circ} 44^{\prime} 03^{\prime \prime} \mathrm{E}\end{array}$ & 380 & -10 & $3500-5500$ & 2 points \\
\hline & Makhinjauri & $\begin{array}{l}41^{\circ} 40^{\prime} 18^{\prime \prime} \mathrm{N} \\
41^{\circ} 42^{\prime} 27^{\prime \prime} \mathrm{E}\end{array}$ & 45 & -9 & $500-1500$ & 0 points \\
\hline \multirow[t]{11}{*}{ Kobuleti } & Dab Chakvi & $\begin{array}{l}41^{\circ} 70^{\prime} 31^{\prime \prime} \mathrm{N} \\
41^{\circ} 72^{\prime} 50^{\prime \prime} \mathrm{E}\end{array}$ & 10 & -12 & $500-700$ & 3 points \\
\hline & Tsikhisdziri & $\begin{array}{c}41^{\circ} 76^{\prime} 075^{\prime \prime} \\
\mathrm{N} \\
41^{\circ} 65^{\prime} 150^{\prime \prime} \\
\mathrm{E}\end{array}$ & 90 & -10 & $900-1200$ & 1 point \\
\hline & Bobokhvati & $\begin{array}{l}41^{\circ} 46^{\prime 2} 22^{\prime \prime} \mathrm{N} \\
41^{\circ} 47^{\prime} 37^{\prime \prime} \mathrm{E}\end{array}$ & 110 & -10 & $800-1600$ & 1 point \\
\hline & Alambari & $\begin{array}{l}41^{\circ} 83^{\prime} 32^{\prime \prime} \mathrm{N} \\
41^{\circ} 86^{\prime} 98^{\prime \prime} \mathrm{E}\end{array}$ & 180 & -9 & $6600-7200$ & 1 point \\
\hline & Achkhvistavi & $\begin{array}{l}41^{\circ} 82^{\prime} 27^{\prime \prime} \mathrm{N} \\
41^{\circ} 90^{\prime} 76^{\prime \prime} \mathrm{E}\end{array}$ & 260 & -11 & $6200-7500$ & 3 points \\
\hline & Mukhaestate & $\begin{array}{l}41^{\circ} 83^{\prime} 98^{\prime \prime} \mathrm{N} \\
41^{\circ} 81^{\prime} 81^{\prime \prime} \mathrm{E}\end{array}$ & 90 & -10 & $4200-5000$ & 2 points \\
\hline & Tskhavroka & $\begin{array}{l}41^{\circ} 51^{\prime} 10^{\prime \prime} \mathrm{N} \\
41^{\circ} 53^{\prime} 21^{\prime \prime} \mathrm{E}\end{array}$ & 180 & -11 & $8000-8400$ & 2 points \\
\hline & PBI & $\begin{array}{l}41^{\circ} 48^{\prime} 40^{\prime \prime} \mathrm{N} \\
41^{\circ} 46^{\prime} 31^{\prime \prime} \mathrm{E}\end{array}$ & 8 & -14 & $800-1000$ & 4 points \\
\hline & Khutsubani & $\begin{array}{l}41^{\circ} 48^{\prime} 13^{\prime \prime} \mathrm{N} \\
41^{\circ} 49^{\prime} 55^{\prime \prime} \mathrm{E}\end{array}$ & 190 & -11 & $3000-4500$ & 1 point \\
\hline & Kondidi & $\begin{array}{l}41^{\circ} 48^{\prime} 51^{\prime \prime} \mathrm{N} \\
41^{\circ} 52^{\prime} 33^{\prime \prime} \mathrm{E}\end{array}$ & 130 & -11 & $5000-5200$ & 2 points \\
\hline & Khala & $\begin{array}{l}41^{\circ} 42^{\prime} 34^{\prime \prime} \mathrm{N} \\
41^{\circ} 47^{\prime} 50^{\prime \prime} \mathrm{E}\end{array}$ & 150 & -11 & $6400-7100$ & 2 points \\
\hline
\end{tabular}

Although we monitored mandarin plantations of up to 250 farmers, the table shows only about 20 plots. In order to get a complete picture of the extent of damage in the subtropical zone of Adjara region in frosty winter conditions, we have included in the table the plots that sharply differed from 
each other: location, proximity to the sea, different altitudes, slope exposure, different soil types, the presence of a windbreak, temperature indicators, garden age, where an accurate assessment of the degree of frost damage was carried out.

The monitoring revealed that although a risky temperature for mandarin crops $\left(-10-11^{\circ} \mathrm{C}\right.$, in some places $-12-14^{\circ} \mathrm{C}$ ) was observed in Adjara region in February 2020, it was not found to be very damaging. Although the degree of frost damage in mandarin plantations was not very high, it was heterogeneous. The degree of frost damage in mandarin plantations with the same temperature but different terrain conditions was significantly different from each other, which is due to the special diversity of the terrain of Adjara, but frost resistance is due to its genetic characteristics and many other factors, such as: plot location, soil type, slope exposure, slope, wind direction, wind speed, garden age, plant habitat, vegetation, leafing frequency, agro-technical works carried out in the garden, number of frosty days, etc.

Most of the 250 observed plantations, the experimental-collection plot of the Institute of Phytopathology and Biodiversity (FBI) in Kobuleti Municipality was damaged (4 points). 100\% of leaves, 1-and 2-year-old seedlings and main branches were damaged. Although the temperature of $14^{\circ} \mathrm{C}$ was observed in the mentioned plot, the high degree of damage was not only due to the low temperature. The experimental plot was young ( 3 years old), planted at the lowest point above sea level (5 m asl), on silty soil (there was a lack of moisture), there was no windbreak and cold air masses rising from the mountain easily reached the plot area. Despite 4 points of damage to the mentioned plot, $90 \%$ of the plants survived and gave us sprouts in the spring.

Mandarin plantations in Kobuleti municipality - Daba Chakvi (5 m asl) were significantly damaged ( 3 points), where the warming effect of the sea was limited by small hills, the plot was located in the valley and suffered from the cold air masses of the mountain. Particularly sensitive and significantly damaged ( 3 points) were the plots (Makho, Achkvistavi) that were cultivated along the river valley and were severely affected by the cold winds of the forests.

The plantations that were cultivated on the steep slope of the northern exposure (Tskhavroka, Alambari, Achkvistavi, Agara), where water was drained from the slopes, were damaged by 2 points. These processes led to soil water depletion and consequently plant plasma was depleted of water, resulting in increased concentration in cell sap and increased acidity. This led to the coagulation of a protein substance in the plasma, which was accompanied by a frost period and the plant was damaged by frost. Plantations on dry and swampy soils where there was frequent water shortages, were also damaged by 2 points.

Despite the rather low temperature $\left(-10-11^{\circ} \mathrm{C}\right)$, the plantations (Makhvilauri, Akhalsheni, Tsikhisdziri, Bobokhvati) that were cultivated at high altitudes on the slope of the southern exposure were slightly damaged (by 1 point). Despite the low temperature, the plantations (Peria, Agara, Makhinjauri, Akhalsheni, Ortabatumi), which are cultivated at relatively high altitudes, on the southern exposure slope and the plot were protected by a windbreak, were not damaged at all (0 point). The monitoring revealed such plots (Gonio, Sarpi) where they were quite damaged even in the conditions of $8^{\circ} \mathrm{C}$. In this situation, the temperature factor is less important, as most of these plantations are older (8090 years old) and depreciated, while some are newly cultivated. No 5-point damage was observed in any of the plantations during the monitoring. $70 \%$ of the monitored plantations gave us a crop, only those plantations that were damaged by 3-4 points were left without harvest.

If we analyze the results of the monitoring, we will come to the conclusion that the damage of mandarin plantations during the frosty winter of 2020 was caused by not only one factor (temperature) but also the damage to the mandarin plantations was supported by the following factors: The autumn period of 2019 was distinguished with warm, dry and cloudy weather, which hindered the moving of plants into the rest position. 2019 was distinguished by the abundant harvest, which is why the food substance was completely spent on the formation of the fetus and the plant's vegetative bodies did not manage to prepare for the winter.

If we analyze the results of monitoring and compare with perennial data (Climate Change, $2013)$, it is clear that in the last century sharply low temperatures (-8-100C, sometimes lower) was observed periodically (once every 5-10 years). From the industrial cultivation of citrus, the exceptionally low temperature has been recorded several times (1910-1911, 1916-1917, 1928-1929, $1944-1945$; 1978-1950, 1963-1964; 1988-1979; 1985-1986), in some years (1910-1911, 1949-1950) 
the plantations were completely frozen and needed to restore them. From 1961 to 2001, there was almost no critical temperature reported to destroy the mandarin plantations, however, freezing of major branches took place in 1964, 1971, 1983 and 1993. In some municipalities (Kobuleti) was a very strict winter in $1985\left(-13,8^{\circ} \mathrm{C}\right)$, which should have caused the complete destruction of citrus plants, but fortunately frost was preceded by abundant snow, whose cover reached 1,5-2,0, which saved plants from freezing. In recent years, the rate of recurrence of severe frosts in winter has been quite reduced. For example, in 1960-1985 severe frosts occurred 5 times, in 1985-2000 - 3 times, while in 2000-2015 - only once, which indicates that the risk of freezing citrus in terms of global changes in climate is gradually decreasing.

Based on the analysis of perennial data, it turns out that if the risk of winter frosts decreased in recent years, the autumn-spring frosts and hail were increasing. For example, in 1985-2015, the hail was observed 10 times, the injuries of the fruit in recent years have been almost systematic. If the last period of strong frosts reduced the recurrence of cases, we cannot say the same about the repetition of hail in autumn, but on the contrary, it is significantly increased, but in this period, there is no low temperature that will result in full destruction of the plant. Based on the data of meteorological stations, it turns out that the frost of the autumn (October-November) or hail takes place almost every second year for subtropical zone of Adjara region, which is directly reflected in the damage of the fetus, but it does not affect the overall condition of the plant.

Conclusions. The monitoring and the analysis of frost damage assessment in the mandarin plantations in the subtropical regions of Adjara region (Kobuleti, Khelvachauri) after frosty winter of 2019-2020 allow us to draw the following conclusions: Although the temperature in Adjara region was quite low (critical for mandarin) $\left(-8-14^{\circ} \mathrm{C}\right)$ in February 2020, the degree of frost damage was not high. This indicates that after the introduction, the citrus has undergone a long time for acclimatizationadaptation and well adapted to our soil-climatic conditions. If earlier in the $-8^{\circ} \mathrm{C}$ temperature conditions mandarin plantations were significantly damaged, today the damage in such temperature conditions is relatively insignificant. In addition, frost resistance is especially high when they are exposed to negative temperatures for a long time, which in our case was not more than 2 days.

Analysis of multi-year data shows that in the last 50 years there has been no critical temperature for the complete destruction of citrus in Georgia, which indicates that the risk of citrus damage from winter frosts in Georgia under global warming is gradually decreasing, although autumnspring frosts have increased. There is no complete mechanism for protecting plants from frost, although it is important to breed frost-resistant varieties that will reduce the risk of citrus freezing by at least $1-2^{\circ} \mathrm{C}$. Making long-term climate forecasts by scientists will even enable agricultural producers to plan cropping strategies in line with climate change.

\section{REFERENCES}

1. Anderson, J.A., L.V. Gusta, D.W. Buchanan, and M.J. Burke. (1983). Freezing of water in citrus leaves. J. Amer. Soc. Hort. Sci. 108: 397-400.

2. Baratashvili D. Khalvashi N. (2016). Biodiversity and Genetic Resources of Aurantioideae in Georgia. Batumi Shota Rustaveli state university, Georgia. P. 364

3. Climate change strategy of Ajara. (2013). The views expressed in this publication are those of the author/s and do not necessarily represent those of the United Nations or UNDP. p 286

4. Davies, F.S. and L.G. Albrigo. (1994). Citrus. CAB International Press. Wallingford, UK. P. 254.

5. Ebel, R.C., Nesbitt, M.L., Dozier, W.A., Lindsey, J.K. and Wilkins, B.S. (2005). A temperature index model to estimate long-term freeze-risk of Satsuma mandarins grown on the Northern coast of the Gulf of Mexico J. Amer. S oc. Hort. Sci. 130: 500 -507

6. Elizbarashvili E. (2017). Climate of Georgia. Georgian Technical University Institute of Hidrometeorology. Tbilisi, pp. 192-198.

7. Fleming, G.H., Olivares-Fuster, O., Del-Bosco, S.F. and Grosser, J.W. (2000). An alternative method for the genetic transformation of sweet orange In Vitro Cellular Dev. Biol. Plant 36: 450- 455.

8. Gerber, J.F. and Hashemi F. (1965). The freezing point of citrus leaves. Proc. Amer. Soc. Hort. Sci. 86: 220-225.

9. Grosser, J.W., Gmitter, F.G., Tusa N. Jr. and Chandler, J.L. (1990). Somatic hybrid plants from sexually incompatible woody species: Citrus reticulata and Citropsis gilletiana. Plant Cell Rpt. 8: 656-659.

10. He, L.G., Wang, H.L., Liu, D.C., Zhao, Y.J., Xu, M., Zhu, M. \& Sunday, Z.H. (2012). Isolation and expression of a cold-responsive gene PtCBF in Poncirus trifoliata and isolation of citrus CBF promoters Biol. Plant. 56: 484 - 492. 
11. Huang, Y., Si, Y. \& Dane, F. (2011) Impact of grafting on cold responsive gene expression in Satsuma mandarin (Citrus unshiu) Euphytica 177: 25- 32.

12. Hodgson, R.W. (1967). "Horticultural varieties of citrus". In The citrus industry, Vol. I. UC Press, Edited by: Reuther, W., Webber, H.J. and Batchelor, L.D. 431-591.

13. Long, G., Song, J., Deng, Z., Liu, J. \& Rao, L. (2012). Ptcorp gene induced by cold stress was identified by proteomic analysis in leaves of Poncirus trifoliata. Mol. Biol. Rpt. 39: 5859 -5866

14. Luth, D. and Moore, G. (1999.) Transgenic grapefruit plants obtained by Agrobacterium tumefaciens mediated transformation Plant Cell Tissue Organ Cult. 57: 219 -222

15. List of varieties and types of subtropical fruit and citrus crops of the USSR (1990). Scientific Research Institute of Plant Industry named after Vavilov, Leningrad, P. 59.

16. Mehtap Șahin-Çevik., Gloria A. Moore Șahin-Çevik, M. and Moore, G.A. (2006). Identification and expression analysis of cold-regulated genes from the cold-hardy Citrus relative Poncirus trifoliata (L.) Raf. Plant Mol Biol 62: 83-97.

17. Moore, G.A., Jacono, C.C., Neidigh, J.L., Lawrence, S.D. and Cline, K. (1992) Agrobacterium-mediated transformation of citrus stem segments and regeneration of transgenic plants. Plant Cell Rpt. 11: $238-242$.

18. Ping Lang, Can-kui Zhang, Robert C., Ebel Fenny Dane, William A., Dozier. (2005) Identification of cold acclimated genes in leaves of Citrus unshiu by mRNA differential display. Gene Volume 359: 111-118.

19. Richard L., Snyder J., Paulo de melo-Abreu (2005). frost protection fundamentals practice and economics. Food and Agriculture Organization of the United Nations. Rome, Volome 1: pp. 3-12

20. Soost R.K, Cameron J.W. (1975). Citrus. In: Janick J, Moore JN(eds) Advances in fruit breeding. University of Purdue.Press, West Lafayette, Indiana, pp. 507-540.

21. Soost R.K, Roose M (1996) Citrus. In: Jules J, Moore JN (eds) Fruit breeding: tree and tropical fruits, vol. 1. John Wiley\& Sons Inc., New York, pp. 257-323.

22. Surguladze Sh. (1975). Auxiliary guide to practical, laboratory work of subtropical plant selection. Tbilisi, pp. 100.

23. Tatarishvili, A. (1980). Interaction of rootstock and grafts in citrus. Publishing House "Science" pp. 98.

24. Thomashow, M.F. (1998). Role of cold-responsive genes in plant freezing tolerance. Plant Physiol. 118: 1-7.

25. Yelenosky, G. (1985). Cold hardiness in citrus. In Horticulture reviews, Edited by: Janick, J. Westport, C.T: AVI Publ. Co., Inc. Vol. 7: 201-238.

26. Yao, J.L., Wu, J.H., Gleave, A.P. and Morris, B.A. (1996). Transformation of citrus embryogenic cells using particle bombardment and production of transgenic embryos Plant Sci. 113: 175 -183.

27. Zhang Can-kui, Ping Lang, Fenny Dane, Robert C. Ebel, Narendra K Singh, Robert D. Locy, William A. Dozier (2005). Cold acclimation induced genes of trifoliate orange (Poncirus trifoliata). Plant Cell Rep. 23: 764 - 769. 